\title{
Characterization and Partial Purification of the Factor(s) Stimulating the Beating of Cultured Myocardial Cells from a Conditioned Medium
}

\author{
Kenzo Ohtsuka and Yuji Tonomura \\ Department of Biology, Faculty of Science, Osaka University, Osaka 560, Japan
}

\begin{abstract}
We previously reported that the beating rate of single myocardial cells cultured in a conditioned medium (CM) was higher than that of cells cultured in a fresh medium. We have characterized and partially purified the beating-stimulating factor(s) of cultured myocardial cells from a conditioned medium of mouse embryonic cells.

The beating-stimulating factor(s) had stable activity for more than one month when it was freeze-dried in $0.1 \mathrm{M}$ sucrose and stored at $-20^{\circ} \mathrm{C}$. The factor(s) was non-dialyzable and was heat-labile. It was inactivated by treatment with trypsin, pronase or hyaluronidase, but not with neuraminidase. These results strongly suggest that the beating-stimulating factor(s) is a glycoprotein(s). When concentrated CM was filtered on Sephadex G-200, the main peak of activity appeared in almost the same fractions as in those for that of hemoglobin. The SDS-polyacrylamide gel electrophoretogram of crude CM showed more than 20 protein bands and about 10 bands stainable by periodic acidSchiff (PAS). In contrast, the electrophoretogram of the active peak on Sephadex G-200 showed about 10 protein bands and one PAS-stainable band.
\end{abstract}

Trypsin-dissociated myocardial cells of mammalian and avian embryos and neonates beat spontaneously in culture $(2,9,13,14)$. Gordon and Wilde (6) reported that when dissociated myocardial cells of chicken embryo were cultured in serum- and protein-free chemically defined medium, less than $1 \%$ of the cells were contractile and less than $2 \%$ spread on glass. About $80 \%$ of the cells were contractile and the percentage of spreading increased remarkably when cells were cultured in a conditioned medium. More recently, Gordon and Brice $(4,5)$ found a spreading factor and a contractile factor in a heart muscle-conditioned medium, and suggested that the former was a substance containing protein and the latter, one containing a glycoprotein.

We previously reported (14) that medium conditioning increased the beating rate of single myocardial cells, and that its effect showed no tissue or species specificity. In this study, we have characterized and partially purified the beating-stimulating factor(s) of myocardial cells from the CM of mouse embryonic cells. Our results strongly indicate that the beating-stimulating factor(s) is a glycoprotein(s) with a molecular weight of about 50,000-70,000 daltons.

\section{MATERIALS AND METHODS}

Preparation of conditioned medium (CM). Mouse embryos 14 to 16 days old were cut into small pieces with scissors after their heads had been excised, and the pieces were subjected to 
stepwise trypsinization. Dissociated cells were collected by gentle centrifugation and resuspended in Eagle's MEM. Plates, $90 \mathrm{~mm}$ in diameter, were inoculated with $2.5 \mathrm{ml}$ of a cell suspension containing about $2-3 \times 10^{7}$ cells. Next, $6 \mathrm{ml}$ of Eagle's MEM and $1.5 \mathrm{ml}$ of calf serum were added and the plates were incubated under an atmosphere of $5 \% \mathrm{CO}_{2}-95 \%$ air at $37^{\circ} \mathrm{C}$ for 2 days. Cells were subcultured in $10 \mathrm{ml}$ of Eagle's MEM supplemented with $10 \%$ calf serum for 1 day. These cells were washed three or four times with Hanks' balanced salt solution to remove serum, then they were cultured in $10 \mathrm{ml}$ of serum-free Eagle's MEM for 4 days. This culture medium was called the crude conditioned medium (crude CM). The amount of protein in the crude CM increased from 5-7 $\mu \mathrm{g}$ to $40-70 \mu \mathrm{g}$ during the 4 days of culture. The crude CM was concentrated by ultrafiltration (UK-10, Toyo) or by precipitation with dialysis against saturated ammonium sulfate. The concentrated crude $\mathrm{CM}$ was dialyzed against Hanks' solution for about $20 \mathrm{~h}$ at $5^{\circ} \mathrm{C}$, then subjected to activity measurement.

Pretreatment of CM with enzymes. Concentrated crude CM in Hanks' solution was pretreated with trypsin (Worthington Biochem.), pronase (Kaken, Japan), hyaluronidase (Sigma, Type I) or neuraminidase (Sigma, Type V) as follows: $0.05 \mathrm{ml}$ of trypsin solution $(1.5 \mathrm{mg} / \mathrm{ml}), 0.05 \mathrm{ml}$ of pronase solution $(0.9 \mathrm{mg} / \mathrm{ml}), 0.05 \mathrm{ml}$ of hyaluronidase solution $(3 \mathrm{mg} / \mathrm{ml})$ or $0.15 \mathrm{ml}$ of neuraminidase solution $(1 \mathrm{mg} / \mathrm{ml})$ was added to $1.5 \mathrm{ml}$ of CM solution $\left(300-500 \mu \mathrm{g} / \mathrm{ml}\right.$ protein), which was then incubated at $37^{\circ} \mathrm{C}$ for $0-90 \mathrm{~min}$. Since the hyaluronidase preparation would be contaminated with a small amount of proteases, we conducted the hyaluronidase treatment in the presence of bovine serum albumin ( 5 times the amount of hyaluronidase) to inhibit the action of proteases. Trypsin digestion was stopped by adding $0.1 \mathrm{ml}$ of trypsin inhibitor solution $(2 \mathrm{mg} / \mathrm{ml})$. The reactions of pronase, hyaluronidase and neuraminidase on CM were stopped by adding $0.4 \mathrm{ml}$ of calf serum, which we had found was effective.

Procedures for measuring beating-stimulating activity. As previously reported (14), heart cells were prepared by the stepwise trypsinization of heart ventricles of 14-16 m day-old mouse embryos. Gelatin-coated plates $(35 \mathrm{~mm}$ in diameter) were inoculated with $0.3 \mathrm{ml}$ portions containing $1 \times 10^{5}$ cells, then $1.0 \mathrm{ml}$ of Eagle's MEM and $0.2 \mathrm{ml}$ of calf serum were added. Hanks' solution $(0.5 \mathrm{ml})$ was added to the control plate, and CM solution $(0.5 \mathrm{ml})$, which had been sterilized by being passed through a Millipore filter (Type HA, $0.45 \mu$ ), was added to the test plate. These plates were incubated under an atmosphere of $5 \% \mathrm{CO}_{2}-95 \%$ air at $37^{\circ} \mathrm{C}$ for $20 \mathrm{~h}$, after which they were washed with Hanks' solution. Then $1.5 \mathrm{ml}$ of Tricine-buffered Eagle's MEM (10 mM Tricine, $\mathrm{pH} 7.4$ ) supplemented with $10 \%$ calf serum was added to the plates for microscopic observation. In this medium, the beating rate of myocardial cells was stable for at least $3 \mathrm{~h}$. The rate was observed at $36-37^{\circ} \mathrm{C}$ using an inverted phase contrast microscope (Nikon, Type MD) with a temperature-regulated chamber. Beating rates of at least 30 single myocardial cells were observed in the test and control plates. The ratio of the average beating rate of the cells in the test plate $\left(\mathrm{ABR}_{\text {test }}\right)$ to the average beating rate of cells in the control plate $\left(\mathrm{ABR}_{\mathrm{con} t}\right)$ indicates that the beatingstimulating activity of the $\mathrm{CM}$ solution was:

$$
\mathrm{ABR} \text { (relative) }=\frac{\mathrm{ABR}_{\text {test }}}{\mathrm{ABR}_{\text {cont }}}
$$

We found that stimulation of the beating rate was proportional to the amount of $\mathrm{CM}$ protein added (see Fig. 1). Therefore, from the observed increase in the beating rate, i.e. ABR (relative) - 1, we could easily calculate the increase when $0.1 \mathrm{mg}$ of $\mathrm{CM}$ protein was added to the plate. This value was also used as the activity per unit protein of a CM preparation.

Disc-gel electrophoresis. The procedures of Weber and Osborne (15) were used for disc gel electrophoresis $[7.5 \%$ acrylamide-bisacrylamide gel with $0.2 \%$ sodium dodecyl sulfate (SDS) 
in $0.1 \mathrm{M}$ sodium phosphate buffer, $\mathrm{pH}$ 7.0]. Protein samples for electrophoresis were prepared in a mixture of $2 \%$ SDS and $10 \% \beta$-mercaptoethanol then boiled for $3 \mathrm{~min}$. The gels were stained to detect protein with Coomassie brilliant blue. To detect carbohydrates, the gels were stained by a method using the periodic acid-Schiff (PAS) reaction (11). Immediately following electrophoresis, the gels were fixed for $1 \mathrm{~h}$ in $12.5 \%$ TCA in test tubes. Next, they were subjected to sample oxidation with $1 \%$ periodic acid for $2 \mathrm{~h}$, then washed for $2 \mathrm{~h}$ against $15 \%$ acetic acid. These steps were all carried out at room temperature. The gels were placed in clean test tubes containing Schiff's reagent and stored in a refrigerator (in the dark) for $2 \mathrm{~h}$. They were destained using several changes of $7 \%$ acetic acid over a 24 -h period.

Protein measurement. Protein was measured by the method of Lowry et al. (12).

\section{RESULTS}

Properties of the beating-stimulating activity in the conditioned medium. The beatingstimulating activity in crude CM was almost unchanged by dialysis against Hanks' solution for more than 1 day. When crude $C M$ was passed through an ultrafilter membrane (UK-10, Toyo), the activity remained in the retentate not the filtrate (Table 1). When the crude CM concentrated by ultrafiltration was fractionated with 0-33, 33-65 and $65-100 \%$ saturated ammonium sulfate solution, activity was observed in all the fractions, and the ratio of activity per unit protein was $2: 1: 2$. As shown in Table 1, when the concentrated crude CM was precipitated with $100 \%$ saturated ammonium sulfate, all the activity was observed in the precipitate.

TABLE 1. EVIDENCE FOR THE MACROMOLECULAR NATURE OF THE BEATINGSTIMULATING FACTOR(S) IN CONDITIONED MEDIUM

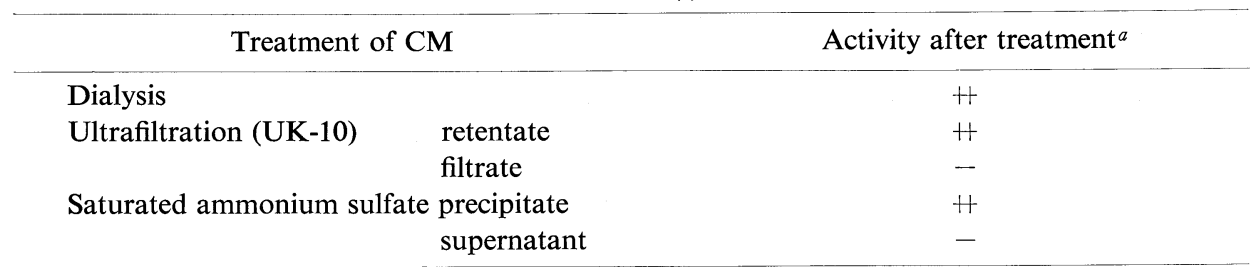

See the text for details of the $\mathrm{CM}$ preparation and assay procedures used for the beating-stimulating activity.

a H: full activity; - : no activity

The beating-stimulating activity of the crude CM concentrated by ultrafiltration was measured within two days of the CM collection. As shown in Fig. 1, the relationship between the activity and the amount of added protein was linear. Thus, the ABR increased two and three times over the values for the control, when 200 and $400 \mu \mathrm{g}$ of CM protein, respectively, were added to a plate.

When the concentrated crude $\mathrm{CM}$ was stored at $4^{\circ} \mathrm{C}$, its activity decreased gradually, as shown in Fig. 2. The activity on the 36th day was about $10 \%$ that of the first day. But when the concentrated crude CM was freeze-dried in $0.1 \mathrm{M}$ sucrose on the seventh day ,the activity showed no further decrease and remained constant for more than one month.

As shown in Table 2, when the concentrated crude $\mathrm{CM}$ was heated at $60^{\circ} \mathrm{C}$ for $30 \mathrm{~min}$ or at $100^{\circ} \mathrm{C}$ for $5 \mathrm{~min}$, its activity decreased to about $30 \%$ of that before heat- 


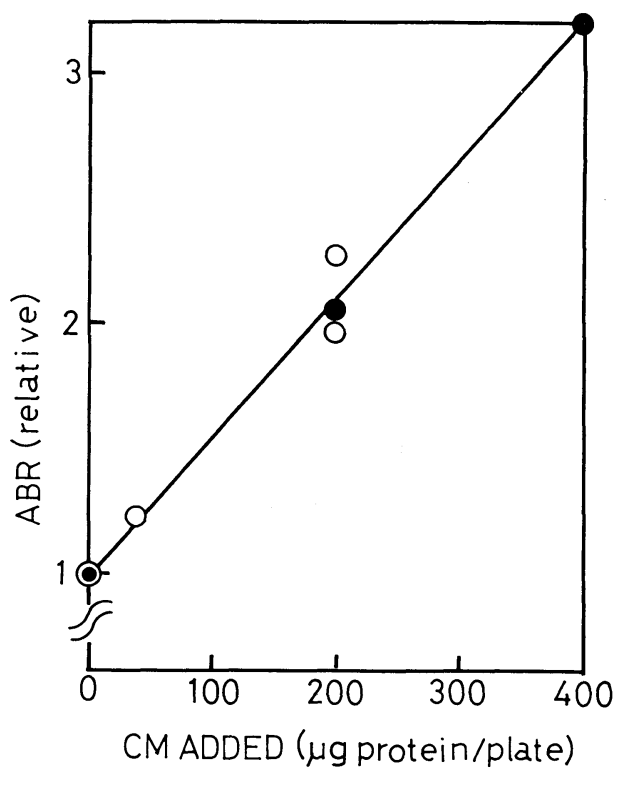

Fig. 1. Dependence of ABR on the concentration of the conditioned medium added. The abcissa gives the amounts of CM protein. See the text for the explanation of the ABR measurements. $\bigcirc$, crude $\mathrm{CM}$ concentrated by ultrafiltration (UK-10, Toyo) ; $\mathbf{O}$, crude CM precipitated by saturated ammonium sulfate.

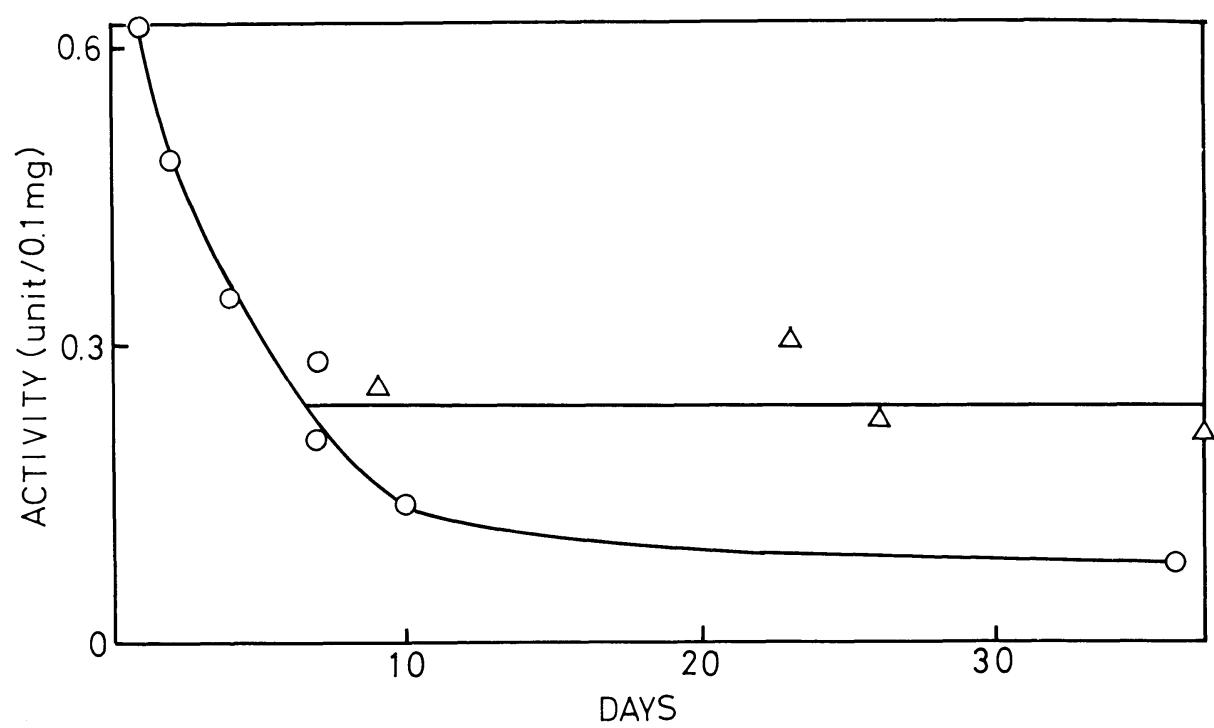

Fig. 2. Stability of the beating-stimulating activity in the conditioned medium. The ordinate gives the activities per $0.1 \mathrm{mg}$ of protein per plate. See the text for details of activity measurements. $\bigcirc, \mathrm{CM}$ stored in Hanks' solution at $4^{\circ} \mathrm{C} ; \triangle, \mathrm{CM}$ freeze-dried on the 7 th day and stored at $-20^{\circ} \mathrm{C}$.

ing (Exp. 1). Activity was completely destroyed by heat treatment at $100^{\circ} \mathrm{C}$ for $15 \mathrm{~min}$ (Exp. 2). When the concentrated CM was treated with $0.025 \mathrm{mg}$ trypsin and $0.015 \mathrm{mg}$ pronase for $30 \mathrm{~min}$, its activity decreased to about 30 and $50 \%$, respectively (Exps. $2,3,4)$. However, activity disappeared almost completely upon treatment with trypsin or pronase for $60 \mathrm{~min}$ (Exps. 2, 4). 
TABLE 2. ACTIVITIES OF THE CONDITIONED MEDIUM AFTER HEATING AND DIGESTION WITH PROTEASES

\begin{tabular}{|c|c|c|c|c|}
\hline \multirow{3}{*}{$\begin{array}{l}\text { CM added } \\
(0.5 \mathrm{ml} / \mathrm{plate})\end{array}$} & \multicolumn{4}{|c|}{ ABR (relative) } \\
\hline & \multicolumn{4}{|c|}{ Experiment } \\
\hline & 1 & 2 & 3 & 4 \\
\hline None & $1.00(0)^{a}$ & $1.00(0)$ & $1.00(0)$ & $1.00(0)$ \\
\hline Untreated & $1.97(100)$ & $1.57(100)$ & $1.91(100)$ & $1.56(100)$ \\
\hline Heated at $60^{\circ} \mathrm{C}$ for $30 \mathrm{~min}$ & $1.30(31)$ & & & \\
\hline Heated at $100^{\circ} \mathrm{C}$ for $5 \mathrm{~min}$ & $1.26(26)$ & & & \\
\hline for $15 \mathrm{~min}$ & & $1.006(1)$ & & \\
\hline Digested with $0.025 \mathrm{mg}$ tryps & & & & \\
\hline for $0 \mathrm{~min}$ & & $1.48(84)$ & $1.66(73)$ & \\
\hline $30 \mathrm{~min}$ & & $1.16(28)$ & $1.32(35)$ & \\
\hline $60 \mathrm{~min}$ & & $1.04(7)$ & & \\
\hline Digested with $0.015 \mathrm{mg}$ pron & & & & \\
\hline for $0 \mathrm{~min}$ & & & & $1.53(95)$ \\
\hline $30 \mathrm{~min}$ & & & & $1.26(47)$ \\
\hline $60 \mathrm{~min}$ & & & & $1.07(12)$ \\
\hline
\end{tabular}

Relative values of the average beating rate [ABR (relative)] representing the ratio of $\mathrm{ABR}$ in the presence and absence of CM. See the text for details of the conditions for trypsin and pronase treatments.

$a$ Values in parentheses indicate the percent of activity, i.e. (ABR tested-1)/(ABR of untreated $\mathrm{CM}-1) \times 100$.

As shown in Table 3, when the concentrated CM was treated with $0.025 \mathrm{mg}$ hyaluronidase for $60 \mathrm{~min}$, activity disappeared completely (Exps. 1,2). The effect of hyaluronidase in the presence of a large amount of bovine serum albumin inhibited protease action, and inactivating effect of $0.025 \mathrm{mg}$ hyaluronidase was almost equal to that of $0.015 \mathrm{mg}$ pronase or $0.025 \mathrm{mg}$ trypsin (Table 3 ). Therefore, it is highly unlikely that

TABLE 3. ACTIVITIES OF THE CONDITIONED MEDIUM AFTER TREATMENTS WITH HYALURONIDASE AND NEURAMINIDASE

\begin{tabular}{|c|c|c|c|c|}
\hline \multirow{3}{*}{$\begin{array}{l}\mathrm{CM} \text { added } \\
(0.5 \mathrm{ml} / \text { plate })\end{array}$} & \multicolumn{4}{|c|}{ ABR (relative) } \\
\hline & \multicolumn{4}{|c|}{ Experiment } \\
\hline & 1 & 2 & 3 & 4 \\
\hline None & $1.00(0)^{a}$ & $1.00(0)$ & $1.00(0)$ & $1.00(0)$ \\
\hline Untreated & $1.69(100)$ & $1.66(100)$ & $1.46(100)$ & $1.50(100)$ \\
\hline \multicolumn{5}{|c|}{ Treated with $0.025 \mathrm{mg}$ hyaluronidase } \\
\hline for $0 \mathrm{~min}$ & $1.64(93)$ & $1.61(92)$ & & \\
\hline $30 \mathrm{~min}$ & $1.60(87)$ & $1.34(52)$ & & \\
\hline $60 \mathrm{~min}$ & $1.01(1)$ & $0.98(-3)$ & & \\
\hline \multicolumn{5}{|c|}{ Treated with $0.05 \mathrm{mg}$ neuraminidase } \\
\hline for $0 \mathrm{~min}$ & & & $1.34(74)$ & 一 \\
\hline $60 \mathrm{~min}$ & & & $1.33(72)$ & $1.45(90)$ \\
\hline $90 \mathrm{~min}$ & & & - & $1.50(100)$ \\
\hline
\end{tabular}

Relative values for the average beating rate [ABR(relative)] show the ratio of $\mathrm{ABR}$ in the presence and absence of CM. See the text for details of the conditions for the hyaluronidase and neuraminidase treatments.

$a$ Values in parentheses show the percent of activity, i.e. (ABR tested-1)/(ABR of untreated $\mathrm{CM}-1) \times 100$. 
the hyaluronidase effect was due to the effect of proteases in the hyaluronidase preparation used. In contrast, when concentrated CM was treated with $0.05 \mathrm{mg}$ neuraminidase for $90 \mathrm{~min}$, its beating-stimulating activity was almost unaffected (Exps. 3, 4). These results strongly suggested that the beating-stimulating factor(s) was macromolecule(s) of a complex of protein with carbohydrate.

Gel chromatography. When the concentrated crude CM was gel filtered on Sephadex G-50, all the beating-stimulating activity was eluted at void volume. When the concentrated CM was filtered on Sephadex G-200 (Fig. 3), the activity was eluted at void volume and fraction numbers 6-12, where hemoglobin (M.W. 65,000) was also eluted. Eluted protein showed a large peak at fractions slightly after the void volume. Also, a small peak appeared at fraction number 15 and a shoulder at fraction number 10 . The highest activity per $0.1 \mathrm{mg}$ protein (fraction number 8 ) obtained by gel chromatography was 1.1 , i.e. the ABR increased 2.1 -fold that of the control on the addition of $0.1 \mathrm{mg}$ protein and activity at the void volume was about half that of fraction number 8 . The void volume fraction might have contained aggregates of the beating-stimulating factor(s), which had a molecular weight of about 50,000-70,000 daltons.

Concentrated crude $\mathrm{CM}$ was also applied to a DEAE-cellulose column $(1.5 \times 5 \mathrm{~cm})$

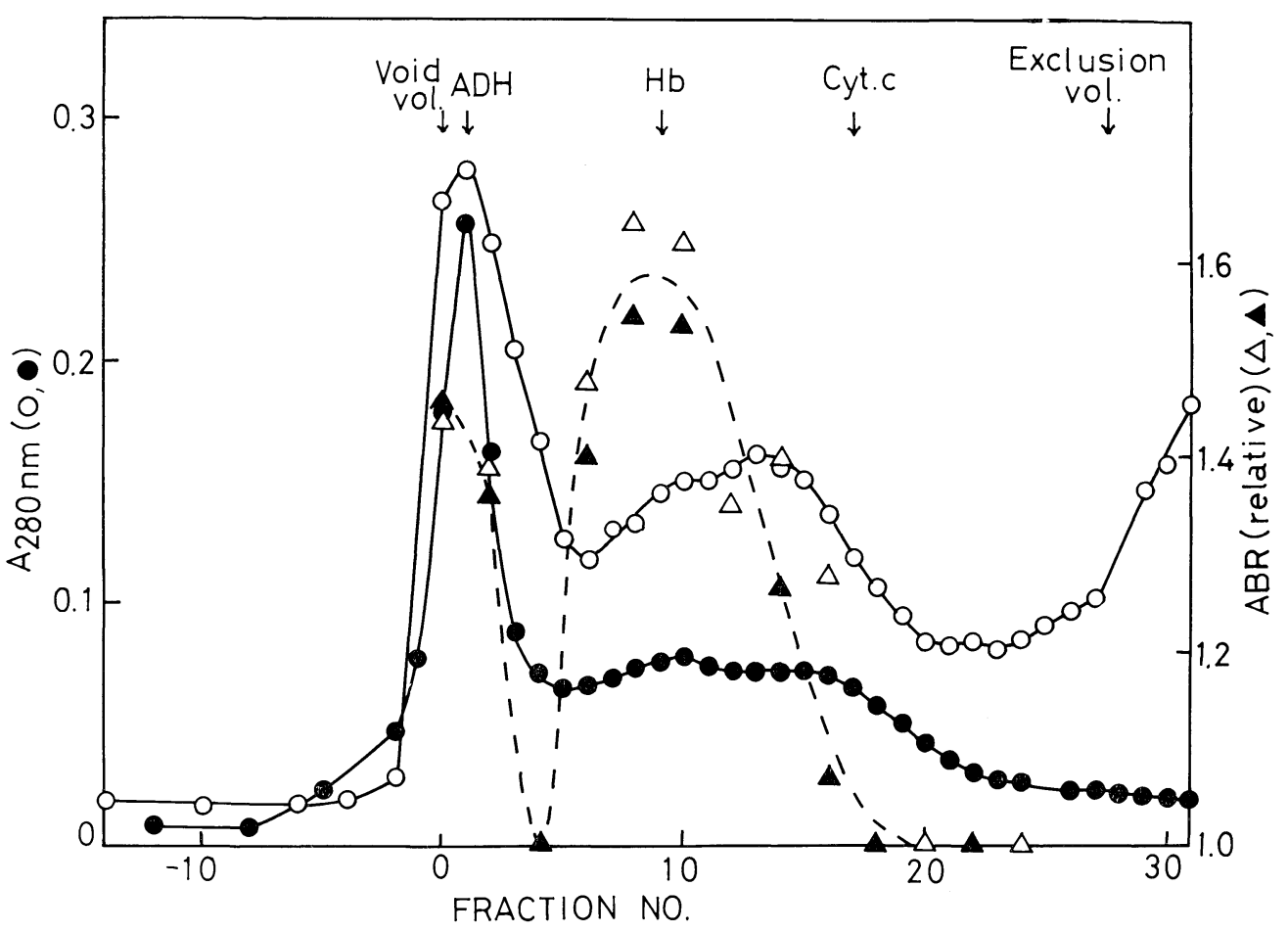

Fig. 3. Gel chromatogram of concentrated CM on Sephadex G-200. Two independent experiments are represented. Void volume was chosen as fraction number 0 . In one series of experiments $(\bigcirc, \triangle)$, a column $2.5 \times 46 \mathrm{~cm}$ was used and the volume of each fraction was $5.0 \mathrm{ml}$. In the other series of experiments $(\boldsymbol{\Delta})$, a column $2.8 \times 35 \mathrm{~cm}$ was used, and the volume of each fraction was $4.5 \mathrm{ml}$. The positions of marker proteins are given for the latter column. ADH, alcohol dehydrogenase (M.W. 151,000); Hb, hemoglobin (M.W. 65,000); Cytc, cytochrome c (M.W. 12,000). 
and eluted stepwise with various concentrations of Hanks' solution. The activities per unit protein at fractions eluted by $0.085 \mathrm{M}$ and $0.107 \mathrm{M}$ of Hanks' solution were more than twice the value for crude CM before column chromatography. A combination of gel filtration and ion exchange column chromatography could have been used to obtain purer factor(s), but large amounts of the starting materials were not available.

SDS-polyacrylamide gel electrophoresis. As shown in Fig. 4, the SDS-polyacrylamide gel electrophoretogram of the concentrated crude CM showed more than 20 protein bands (A) and about 10 PAS-stainable bands (B). On the other hand, the gel electrophoretogram of a high activity fraction from Sephadex G-200 (fraction numbers $6-12$ in Fig. 3) showed about 10 protein bands (C) and one PAS-stainable band (D). The one PAS-stainable band seen in Fig. 4D may be the beating-stimulating factor, although other possibilities can not be excluded as there were about 10 protein bands in $\mathrm{C}$ which might include glycoprotein(s) with a carbohydrate moiety that was undetectable with the PAS-staining method. The gel electrophotograms of calf serum shown in $\mathrm{E}$ and $\mathrm{F}$ of the protein band and the PAS-stainable band, respectively, had remarkably different patterns from those of crude CM.

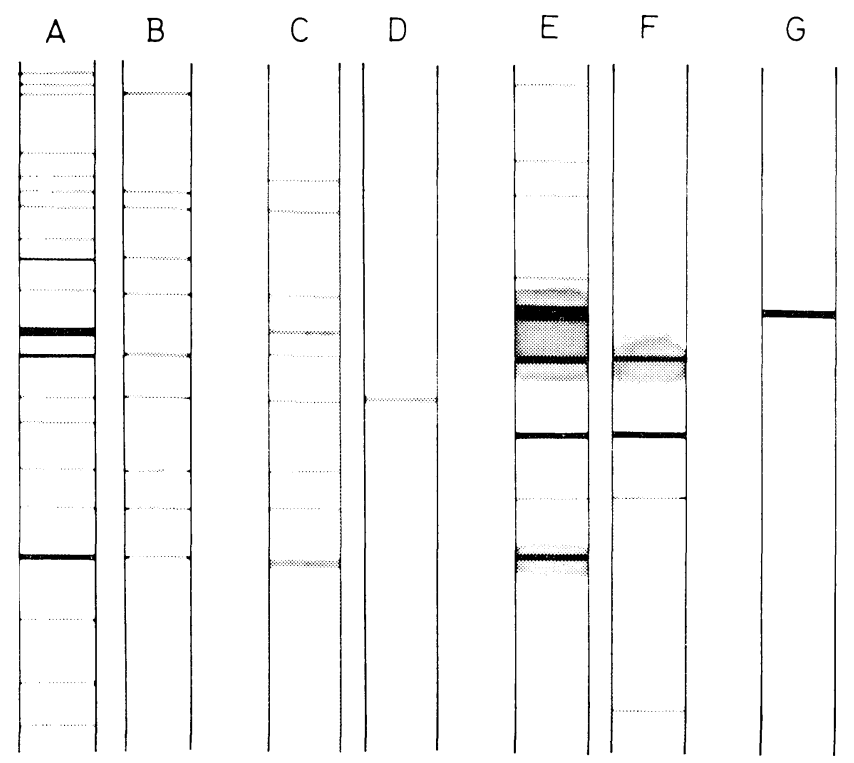

Fig. 4. SDS-polyacrylamide gel electrophoretograms of the conditioned medium. A, C, E, G, stained with Coomassie brilliant blue; B, D, F, stained by the PAS reaction. A, B, concentrated crude CM; C, D, active fractions obtained by Sephadex G-200 gel chromatography (fraction numbers 6-12 in Fig. 3); E, F, calf serum; G, bovine serum albumin.

\section{DISCUSSION}

The results summarized in Tables 1, 2 and 3 strongly suggest that the beating-stimulating factor(s) in a conditioned medium (CM) of mouse embryonic cells is a complex of protein with carbohydrate [glycoprotein(s)]. Gordon and Brice (5) have reported that the contractile factor which promotes the percentage of beating cells is also a protein-carbohydrate complex. While our beating-stimulating factor(s) was complete- 
ly inactivated by heat treatment at $100^{\circ} \mathrm{C}$ for $15 \mathrm{~min}$, their contractile factor was fairly heat-stable. Thus, their contractile factor was inactivated only $10 \%$ by heating it at $100^{\circ} \mathrm{C}$ for $10 \mathrm{~min}$. Our factor(s) resembled theirs with respect to such other properties as inactivation by trypsin and hyaluronidase and its resistance to neuraminidase.

The possibility that the beating-stimulating factor(s) was derived from calf serum is most unlikely. If it existed in calf serum, then the myocardial cells cultured in a high concentration of calf serum should have shown higher ABRs. However, the ABR was nearly constant in $5-30 \%$ calf serum. Furthermore, the gel electrophoretogram of the crude CM differed remarkably from that of calf serum (Fig. 4) and almost all the proteins in CM were produced by cells, as described in "Materials and methods."

When norepinephrine $(1,3,7,16)$ or dibutyryl cyclic AMP $(8,10)$ is added to cultured myocardial cells, the beating rate increases immediately. However, in our study, the effect of concentrated CM was not observed 2-3 $\mathrm{h}$ after it had been added to the cultured myocardial cells. The factor(s) in CM may affect the excitation processes of the cell membrane or promote metabolic processes in the cells and increase the beating rate as a secondary effect, after being incorporated into the cell membrane. As described in "Results" ( $c f$. Fig. 3), the most active fraction obtained by gel filtration increased the ABR two fold when $85 \mu \mathrm{g}$ of its protein was added per plate. This active fraction contained only one PAS-stainable band ( $c f$. Fig. 4), and the protein content of this band was estimated to be about $6 \%$ of the total protein of the active fraction. Therefore, if we assume that this band is actually the active component, we can conclude that $5 \mu \mathrm{g}$ of protein of the active factor per plate increases the ABR two fold. This suggests that the function mechanism of the beating-stimulating factor is very specific. Its effect on myocardial cells, however needs to be clarified. We also do not know whether it affects other cell functions. The beating-stimulating factor(s) must be further purified before attempting to solve these problems. The function of our factor(s) on the beating and other properties of the heart in situ is also unknown. To solve this problem, we must investigate the effects of the factor(s) on the physiological activities of the myocardial cell sheet, after further purification of the factor(s).

Acknowledgments. We are indebted to Dr. K. Goshima of the Faculty of Science, Nagoya University for his stimulating discussions during the course of this work. This study was supported by grants from the Muscular Dystrophy Association, Inc. and the Ministry of Education, Science and Culture of Japan.

\section{REFERENCES}

1. Chang, T.D. and G.R. Cumming. Chronotropic responses of human heart tissue cultures. Circ. Res. 30, 628-633, 1972

2. DehaAN, R.L. Regulation of spontaneous activity and growth of embryonic chick heart cells in tissue culture. Dev. Biol. 16, 216-249, 1967

3. Ertel, R.J., D.E. Clarke, J.C. Chao and F.R. Franke. Autonomic receptor mechanisms in embryonic chick myocardial cell culture. J. Pharmacol. Exp. Ther. 178, 73-80, 1971

4. Gordon, H.P. and M.C. BRICE. Intrinsic factors influencing the maintenance of contractile embryonic heart cells in vitro. I. The heart muscle conditioned medium effect. Exp. Cell Res. 85, 303-310, 1974

5. Gordon, H.P. and M.C. BRICE. Intrinsic factors influencing the maintenance of contractile embryonic heart cells in vitro. II. Biochemical analysis of heart muscle conditioned medium. Exp. Cell Res. 85, 311-318, 1974

6. Gordon, H.P. and CH.E. WILdE. "Conditioned" medium and heart muscle differentiation: 
Contrast between explants and disaggregated cells in chemically defined medium. Exp. Cell Res. 40, 438-442, 1965

7. Goshima, K. Initiation of beating in quiescent myocardial cells by norepinephrine, by contact with beating cells and by electrical stimulation of adjacent FL cells. Exp. Cell Res. 84, 223-234, 1974

8. Goshima, K. Antagonistic influence of dibutyryl cyclic AMP and dibutyryl cyclic GMP on the beating rate of cultured mouse myocardial cells. J. Mol. Cell. Cardial. 8, 713-725, 1976

9. Goshima, K. and Y. Tonomura. Synchronized beating of embryonic mouse myocardial cells mediated by FL cells in monolayer culture. Exp. Cell Res. 56, 387-392, 1969

10. Krause, E.G., Halle and A. Wollenberger. Effect of dibutyryl cyclic GMP on cultured beating rat heart cells. In Advances in Cyclic Nucleotide Research, Vol. 1, ed. GreENGARD, P. and G.A. Robinson, Raven Press, New York, pp. 301-305, 1972

11. Kapitany, R.A. and E.J. Zebrowski. A high resolution PAS stain for polyacrylamide gel electrophoresis. Anal. Biochem. 56, 361-369, 1973

12. Lowry, O.H., N.J. Rosenbrough, A.L. Farr and R.J. Randall. Protein measurement with the Folin phenol reagent. J. Biol. Chem. 193, 265-275, 1951

13. MARK, G.E. and F.F. STRASSER. Pacemaker activity and mitosis in cultures of newborn rat heart ventricle cells. Exp. Cell Res. 44, 217-233, 1966

14. Ohtsuka, K. and Y. Tonomura. Effects of conditioning the medium on the beating of single myocardial cells in vitro. Cell Struct. Funct. 1, 11-21, 1975

15. Weber, K. and M. Osborn. The reliability of molecular weight determination by dodecyl sulfate-polyacrylamide gel electrophoresis. J. Biol. Chem. 244, 4406-4412, 1969

16. Wollenberger, A. Rhythmic and arrhythmic contractile activity of single myocardial cells cultured in vitro. Circ. Res. 14 and 15, Suppl. 2, 184-201, 1964

(Received for publication, October 31, 1977) 